\title{
Oxidative Stress Biomarkers and Adenosine Deaminase over the Alopecic Area of the Patients with Alopecia Areata
}

\author{
Perihan Öztürk ${ }^{1}$, Özer Arıcan ${ }^{2}$, Ergül Belge Kurutaş ${ }^{3}$ Kamil Mülayim $^{1}$ \\ ${ }^{1}$ Department of Dermatology, Kahramanmaraş Sütçüimam University School of Medicine, Kahramanmaraş, Turkey \\ ${ }^{2}$ Department of Dermatology, Fatih University School of Medicine, İstanbul, Turkey \\ ${ }^{3}$ Department of Biochemistry, Kahramanmaraş Sütçüimam University School of Medicine, Kahramanmaraş, Turkey
}

Background: Alopecia areata (AA) is an autoimmune, T-cell mediated, and chronic inflammatory disorder. The pathological mechanisms of disease are unclear, but oxidative stress may be involved. To our knowledge, no studies have examined the oxidative stress levels or biomarkers within the lesional area and skin surface in patients with AA. Similarly, adenosine deaminase (ADA) has not been characterized in AA.

Aims: Therefore, we aimed to define ADA levels and the factors involved in oxidative stress from scalpscrapes of patients with AA.

Study Design: Case-control study.

Method: A total of 60 patients (30 diagnosed AA patients and 30 healthy controls) were included in the study. ADA as well as oxidative stress factors, including malondialdehyde (MDA), reduced glutathione
(GSH), superoxide dismutase (SOD) and catalase (CAT) were analyzed from scalp-scrapes in both groups and quantified by spectrophotometry.

Results: Activities of SOD ( $\mathrm{p}=0.000), \mathrm{CAT}(\mathrm{p}=0.033)$, and $\operatorname{ADA}(p=0.004)$ as well as levels of GSH $(p=0.000)$ and MDA $(p=0.032)$ in patients with AA were higher than the controls statistically significant.

Conclusion: Based on these results, factors associated with oxidative stress were elevated in AA patient scalpscrapes compared to controls and may have a defined role the disease pathogenesis. Alterations in the activities of antioxidant enzymes from AA patient scraping samples may be a local effect of elevated oxidative stress levels. In this disease, oxidative stress may affect not only hair follicle but also any layers of the skin.

Keywords: Adenosine deaminase, alopecia areata, antioxidant, oxidative stress
Alopecia areata (AA) is a typical autoimmune and persistent T-cell mediated inflammatory disorder of the hair and nails. Patients with AA often develop smooth discrete areas of complete non-scarring hair loss. It occurs in either sex and at any age (1). Approximately $1.7 \%$ of the population will experience an episode of AA during their lifetime $(1,2)$. The etiopathogenesis of the disease is still poorly understood; and therefore, no effective treatments are available. Because of this, the disease may adversely affect the quality of life of the patients (3).
In normal aerobic cells there is a present balance between antioxidant protection and oxidative damage. Reactive oxygen species (ROS) cause oxidative stress due to the loss of antioxidant protection or excess production (4-8). Several factors that contribute to oxidative stress, including superoxide dismutase (SOD), catalase (CAT), and reduced glutathione (GSH) closely linked to various oxidative stress responses (9). In addition, malondialdehyde (MDA), the end product of lipid peroxidation, is also an indicator of oxidative stress (10). Adenosine deaminase (ADA) is noted a marker of T-cell activation (11).

This study was presented at the $30^{\text {th }}$ Congress of The European Academy of Allergy and Clinical Immunology, 11-15 June 2011, İstanbul, Turkey.

Address for Correspondence: Dr. Perihan Öztürk, Department of Dermatology, Kahramanmaraş Sütçüimam University School of Medicine, Kahramanmaraş, Turkey Phone: +905325745881 e-mail: drperihanozturk@hotmail.com

Received: 14 April 2015 Accepted: 27 October 2015 • DOI: 10.5152/balkanmedj.2016.16190

Available at www.balkanmedicaljournal.org 
There are a few studies demonstrating an association between the oxidative stress in serum and biopsy samples in AA (10,12-15). However, there is no data about the oxidative stress of the skin surface on the lesional area of patients with AA in the literature. Additionally, the role of ADA as a marker for AA has not been examined. New knowledge on the local antioxidant system and ADA activities in AA may help to understand the pathogenesis of the disease and its treatment modalities. Examination of AA patient scalp-scrapes for oxidative stress factors is discussed.

\section{MATERIALS AND METHODS}

The study was granted by the university ethics committee and each subject signed an informed consent form prior to initiation of the study. Thirty diagnosed AA patients and 30 healthy controls were included in the study. After informed consent was received, scalp scrape samples were obtained from AA patients and normal controls. The data collection was performed for six months (from April to September 2011). For consistency, the AA diagnosis was was made by the same dermatologist, which is based onthe National Alopecia Areata Foundation guidelines. Further confirmation of the diagnosis was determined by laboratory and histology investigations. Patients that had hair loss due to other causes such as concurrently patterned baldness were not included in the study. Patients of either sex, older than 10 years of age, and patients with up to two alopecic plaques were enrolled at a single hospital. Patients that had disease duration of more than three months, previously treated patients for AA or totalis, universalis, and/or ophiasis types were not included. In addition, patients with a BMI in the 'obese' range were also exluded. The patients that were enrolled in the study did not have: (1) a medical history of topical and/or systemic drug treatment; (2) administration of anti-inflammatory drugs and vitamins (in the last three months); and (3) any another concurrent systemic and/or cutaneous diseases. Neither the AA patients nor the controls had any symptoms of mental and/or physical from zinc deficiency. None of the patients and controls had alcohol abuse problems and smoking. None of the females enrolled were expecting or lactating. Scalp-scrape samples were collected with a scalpel blade (until bleeding) from the alopecic skin regions in the AA patients and from any scalp region of the controls using the same dermatologist. Scalp-scrapes were aliquotted and stored $\left(-80^{\circ} \mathrm{C}\right)$ for later determination of the factors associated with oxidative stress, including the activity of SOD, CAT, and ADA, as well asexpression of GSH, and MDA.

\section{Laboratory and biochemical assays}

\section{Scalp-scrape preparation and homogenates}

Scalp-scrapings were prepared by homogenization in $1.15 \%$ ice-cold potassium chloride as previously described. Briefly, supernatants were subjected to centrifugation at $14,000 \mathrm{rpm}$ for $30 \mathrm{~min}$ at $+4^{\circ} \mathrm{C}$. Quantification of total protein levels for each homogenate was done using the Lowry method (16).

\section{ADA activity}

Adenosine deaminase activity was quantified using a method determined by Beutler (17). The assay homogenate consisted of $20 \mu \mathrm{L}$ of the scraping sample in $100 \mu \mathrm{L}$ of a $1 \mathrm{M}$ Tris/ EDTA ( $5 \mathrm{mM}$ ) buffer (pH 8.0) and $20 \mu \mathrm{L}$ of $4 \mathrm{mM}$ adenosine (freshly prepared) in a total volume of $1 \mathrm{~mL}$. Samples were examined for enzyme activity using a photospectometer to measure absorbance at $265 \mathrm{~nm}$ and expressed as U/mg protein.

\section{CAT activity}

Catalase activities were measured by quantifying the reduction of hydrogen peroxide $\left(\mathrm{H}_{2} \mathrm{O}_{2}\right)(230 \mathrm{~nm})(17)$. The assay was performed in a $1 \mathrm{M}$ Tris buffer $(\mathrm{pH} 7)$ containing $5 \mathrm{mM}$ EDTA, $1 \mathrm{M}$ phosphate, and $10 \mathrm{mM} \mathrm{H}_{2} \mathrm{O}_{2}$. Units for cat activity were expressed as $\mathrm{U} / \mathrm{mg}$ protein.

\section{SOD activity}

Superoxide dismutase activity was determined as previously described (18). The assay buffer was made up of $10 \mathrm{mM}$ phosphate, $50 \mathrm{mM}$ CAPS (3-cyclohexilamino-1- propanesulfonicacid), $940 \mu \mathrm{M}$ EDTA and saturated $\mathrm{NaOH}$ (pH 10.2). Before the assay, the substrate [50 $\mu \mathrm{M}$ xanthine, $0.025 \mathrm{mM}$ INT (p-iodonitrotetrazolium violet)] and $80 \mathrm{U} / \mathrm{L}$ xanthine oxidase was added to the assay and measured at $505 \mathrm{~nm}$ (SOD activity was recorded as $\mathrm{U} / \mathrm{mg}$ protein.

\section{Determination of GSH and MDA levels}

Glutathione was measured using a reduction reaction at room temperature, where DTNB (5, 5'-Dithiobis (2-nitrobenzoic acid)) reacts with non-protein sulfhydryl compounds as previously described (17). The reduction of non-protein sulfhydryls were measured within the first 10 minutes at a wavelength of $412 \mathrm{~nm}$. GSH levels were recorded as $\mu \mathrm{mol} / \mathrm{mg}$ protein.

Malondialdehyde levels were determined by quantifying thelipid peroxidation levels from scalp-scrapes using a method by Ohkawa. (19). The reaction mixture consisted of 100 $\mu \mathrm{L}$ of scalp-scrape, $8.1 \%$ SDS $(0.2 \mathrm{~mL}), 20 \%$ acetic acid and $0.8 \%$ thiobarbituric acid (TBA) $(1.5 \mathrm{~mL}$ each). The assay medium was titrated to a $\mathrm{pH} 3.5$ and the total volume adjusted to $4.0 \mathrm{~mL}$ with distilled water. Finally, $5.0 \mathrm{~mL}$ of n-butanol and pyridine (15:1, vol/vol) were added and forcefully agitated. 
Following centrifugation (4,000 rpm for $10 \mathrm{~min})$, the organic layer was collected and absorbance was measured at a wavelength of $532 \mathrm{~nm}$. MDA was recorded as $\mathrm{nmol} / \mathrm{mg}$ protein.

\section{Statistical analysis}

Sample size was determined by a power analysis (power $=0.99$, $\alpha=0.05$ ). Statistics was done using SPSS 17.0 for Windows (SPSS Inc; IL, Chicago, USA). The conformability to the normal distribution was investigated by One sample KolmogorovSmirnov test. Since gender and age were of normal distribution, data was recorded as mean \pm standard deviation $(\mathrm{SD})$. An unpaired student's t-test was performed for between group comparisons of the average. Since MDA levels did not have a normal distribution, a Mann-Whitney U-test was implemented. The data was presented as median, minimum, and maximum. Statistical significance was determined if the $\mathrm{p}$-value was less than 0.05 .

\section{RESULTS}

The AA patient group $(\mathrm{n}=30)$ included seventeen males and thirteen females [mean age $=25.7 \pm 8.5$ years (range; $10-40$, median; 25 years]. The control subjects $(n=30)$ was evenly matched and consisted of sixteen males and fourteen females [mean age $=26.6 \pm 6.8$ years (range; $17-43$, median; 25 years]. The mean duration of AA was $1.83 \pm 0.48$ months (range; $1-3$ months). There was a single plaque in 11 patients and two plaques in 19 patients. There were no nail findings in any of the patients tested. No statistically significant difference was observed for age and gender $(\mathrm{p}=0.65)$. The activities of SOD, CAT and ADA and the levels of MDA and GSH are shown in Table 1. All activities and levels determined from the AA patients were statistically elevated compared to controls. The results also are graphically presented in Figure 1. No statistically significant difference was observed in the AA patients with one or two lesions $(\mathrm{p}=0.78)$.

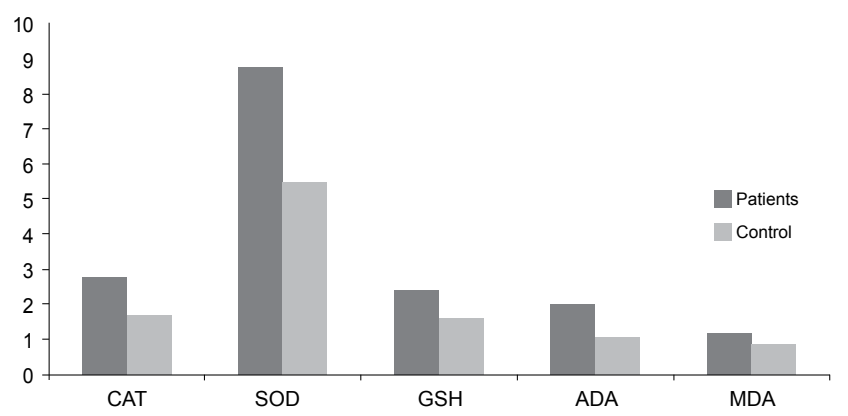

FIG. 1. Oxidative stress biomarkers and ADA in scraping samples of with alopecia areata and control subjects

(CAT: catalase; SOD: superoxide dismutase; GSH: reduced glutathione; ADA: adenosine deaminase; MDA: malondialdehyde)
TABLE 1. The Demographic values and the activities of CAT, SOD, and ADA as well as GSH and MDA levels from scalp-scrapes of patients with alopecia areata and controls

\begin{tabular}{lccc}
\hline & $\begin{array}{c}\text { Patients } \\
\text { Mean } \pm \text { SD } \\
\text { Parameters }\end{array}$ & $\begin{array}{c}\text { Controls } \\
\text { Mean } \pm \text { SD } \\
\text { (Med, Min-Max) }\end{array}$ & $\begin{array}{c}\mathrm{p} \\
\text { (Med, Min-Max) }\end{array}$ \\
\hline Age (years) & $25.7 \pm 8.5$ & $26.6 \pm 6.8$ & 0.65 \\
Gender (n) F/M & $(25,10-40)$ & $(25,17-43)$ & \\
CAT & $17 / 13$ & $16 / 14$ & 0.65 \\
& $2.74 \pm 0.95$ & $1.68 \pm 0.70$ & $0.033^{*}$ \\
SOD & $(2.69,1.07-4.79)$ & $(1.46,0.87-3.61)$ & \\
& $8.78 \pm 3.11$ & $5.46 \pm 2.08$ & $0.000^{*}$ \\
GSH & $(8.77,4.56-16.02)$ & $(5.16,2.00-9.45)$ & \\
& $0.24 \pm 0.06$ & $0.16 \pm 0.05$ & $0.000^{*}$ \\
MDA & $(0.25,0.13-0.34)$ & $(0.16,0.09-0.29)$ & \\
& $117.80 \pm 62.20$ & $83.94 \pm 27.33$ & $0.032^{* *}$ \\
ADA & $(103.61,7.92-325.89)$ & $(80.00,53.20-175.96)$ & \\
& $1.99 \pm 0.66$ & $1.07 \pm 0.76$ & $0.004^{*}$ \\
\hline
\end{tabular}

CAT: catalase; SOD: superoxide dismutase; GSH: reduced glutathione; MDA: malondialdehyde; ADA: adenosine deaminase

CAT, SOD and ADA were expressed as U/mg protein, MDA was expressed as nmol/mg protein and GSH was expressed as micromol/mg protein

${ }^{*}$ Student $\mathrm{t}$ test, ${ }^{* *}$ Mann Whitney-U Test.

\section{DISCUSSION}

In the current report, we demonstrated significantly elevated activities of CAT, SOD, and ADA, as well as increased GSH and MDA in the lesions of patients with AA compared to the scalp of the control group. As described above, there are limited studies demonstrating correlation with oxidative stress and AA.

Alopecia areata is characterized by conspicuous changes in the capillaries of the dermal vasculature and the existence of epidermal and dermal inflammatory cells. AA is known to occur due to aberrant lymphokine secretion, eicosanoid metabolism, and fatty acid metabolism (12). Also, AA presents with infiltration of inflammatory cells that surround the hair follicle. This infiltrate commonly causes hair follicle destruction and abnormal keratinization (20). The intracellular production of ROS that leading to oxidative cellular damage is elevated by infiltrating inflammatory cells and also by synthesized cytokines. TNF- $\alpha$ stimulates intracellular production of mitochondrial ROS. An impaired cellular antioxidant defense mechanism can induce aberrant lipid peroxidation in cellular membrane (21).

The increased activity of ADA found in our work may be gauge of inflammatory cell activation in AA patients. The origin of this activity may be due to the increased infiltration of T-lymphocytes in the lesions of these patients. Increased ADA activity may be involved in hyperproliferation and differen- 
tiation of lymphocytes (where it has high activity). It is also thought that in AA, deranged immunity may also originate from cellular cytotoxic responses that have control over Tlymphocyte function. Such non-specific cellular immune responses, described as one of the possible mechanisms responsible for the production of lymphocytotoxins, were observed earlier in autoimmune diseases where elevated ADA levels have also been detected (21-23). Indeed, AA also can be associated with autoimmune diseases (24). According to our literature investigation, ADA has not been studied in AA until now. Our study of ADA activity in AA individuals is the first of its kind to be described in an immunological context. We put forth the notion that increased ADA may have the activation criteria to drive the cell-mediated immunity in the pathophysiology of AA.

Glutathione is the foremost non-enzymatic antioxidant found in cells. It binds and acts as a substrate for GSH peroxidase and scavenges ROS. Elevated intracelluar GSH levels may have a critical role in protecting cells from oxidative stress and maintaining the immune system in AA. Our results for GSH are similar to Akar et al. (13). However, Naziroglu and Kokcam (12) observed that levels of GSH and glutathione peroxidase in both plasma and erythrocytes were statistically reduced in AA patients compared to a control group. We believe that the levels of GSH in patients with AA may be another important link between the immunity and the oxidative stress. Because of the controversial results in the studies, new and detailed studies should be planned in the peripheral blood and the lesional area of patients with $\mathrm{AA}$ in the future.

The SOD-CAT system is key for antioxidant defense. SOD is localized to the cytoplasm and generates $\mathrm{H}_{2} \mathrm{O}_{2}$. In addition, SOD provides protection from the cytotoxic effects of superoxide radicals. However, CAT destroys $\mathrm{H}_{2} \mathrm{O}_{2}$, generating water and oxygen. It reported that otoimmune disorders like patients with PV have significantly higher antioxidant enzyme activities (25). Our study demonstrated an increase in SOD and CAT activities. This is most likely a defense mechanism to regulate the excessive oxidative stress. Our findings indicate that increased SOD and CAT activities may not be enough to regulate the superoxide radical production, since other radicals may be produced and not readily broken down by SOD and CAT. Our results for SOD were similar to Akar et al.(13) in contrast to the other studies $(10,14)$. However, the activity of CAT in patients with AA was not measured in all of the three studies. The discrepancies observed in the results may be an effect of the different laboratory techniques used, different samples (such as serum or tissue) analyzed, different inclusion/exclusion criteria for selection of the cohorts, or a compensatory mechanism of the body.
Furthermore, we found that MDA levels increased about two-fold in AA compare to the healthy controls. Consistent with this, MDA levels from the serum or the tissue of AA patients were elevated in all previous studies similar to Behcet's Disease $(10,12-14,26)$. Indeed, MDA is proportional to the degree of lipid peroxidation and is a gold standard for evaluating oxidative stress (20). Based on this, lipid peroxidation may be heavily involved in the pathobiology of AA.

In conclusion, our results indicate that oxidative damage is prominent in AA and may have a role in its pathogenesis. The altered antioxidant enzyme activities from the patient scalpscrapes may be local response to the elevated oxidative damage. In this disease, oxidative stress may affect, not only hair follicle, but also any/all layers of the skin.

\section{Study limitations}

A few limitations were noted in the present report. The patient sample size was a small and a larger population would be necessary to validate our findings. The extent of the disease was less than three months. Severe and generalized forms of AA were not included in our study. Furthermore, the prognosis of the disease also was not observed in this study.

Ethics Committee Approval: Ethics committee approval was received for this study from the ethics committee of Kahramanmaraş Sütçüimam University.

Informed Consent: Written informed consent was obtained from patients who participated in this study.

Peer-review: Externally peer-reviewed.

Author contributions: Concept - P.Ö., Ö.A.; Design - P.Ö.; Supervision - E.K., P.Ö.; Resource - P.Ö.; Materials - K.M.; Data Collection and/or Processing - P.Ö., Ö.A.; Analysis and/or Interpretation - P.Ö.; Literature Search - P.Ö.; Writing - P.Ö., Ö.A.; Critical Reviews - Ö.A.

Conflict of Interest: No conflict of interest was declared by the authors.

Financial Disclosure: The authors declared that this study has received no financial support.

\section{REFERENCES}

1. Madani S, Shapiro J. Alopecia areata update. J Am Acad Dermatol 2000;42:549-66. [CrossRef]

2. Cotsarelis G, Botchkarev V: Disorders of the hair and nails. In: Wolf K, Goldsmith LA, Katz SI, Gilchrest BA, Paller AS, Leffell DJ (eds): Fitzpatrick's Dermatology General Medicine. 7rd edn. New York: McGraw- Hill Companies, 2008 pp. 739-96. 
3. Güleç AT, Tanriverdi N, Dürü C, Saray Y, Akçali C. The role of psychological factors in alopecia areata and the impact of the disease on the quality of life. Int J Dermatol 2004;43:352-6. [CrossRef]

4. Löntz W, Sirsjö A, Liu W, Lindberg M, Rollman O, Törmä H. Increased mRNA expression of manganese superoxide dismutase in psoriasis skin lesions and in cultured human keratinocytes exposed to IL-1 beta and TNF-alpha. Free Radic Biol Med 1995;18:349-55. [CrossRef]

5. Thérond P, Gerbaud P, Dimon S, Anderson WB, Evain-Broin D, Raynaud F. Antioxidant enzymes in psoriatic fibroblasts and erythrocytes. J Invest Dermatol 1996;106:1325-8. [CrossRef]

6. Niwa Y, Kanoh T, Sakane T, Soh H, Kawai S, Miyachi Y. Detection of enhanced lipid peroxide levels in patients with inflammatory skin diseases. J Clin Biochem Nutr 1987;2:245-51. [CrossRef]

7. Emerit I. Free radicals and aging of the skin. EXS 1992;62:32841. [CrossRef]

8. Miyachi Y. Photoaging from an oxidative standpoint. J Dermatol Sci 1995;9:79-86. [CrossRef]

9. Sies H. Oxidative stress: from basic research to clinical application. Am J Med 1991;1:31-8. [CrossRef]

10. Abdel Fattah NSA, Ebrahim AA, El Okda ES. Lipid peroxidation/antioxidant activity in patients with alopecia areata. $J$ Eur Acad Dermatol Venereol 2011;25:403-8. [CrossRef]

11. Desrosiers MD, Cembrola KM, Fakir MJ, Stephens LA, Jama FM, Shameli A, et al. Adenosine deamination sustains dendritic cell activation in inflammation. J Immunol 2007;179;1884-92. [CrossRef]

12. Naziroglu M, Kokcam I. Antioxidants and lipid peroxidation status in the blood of patients with alopecia. Cell Biochem Funct 2000;18:169-73. [CrossRef]

13. Akar A, Arca E, Erbil H, Akay C, Sayal A, Gür AR. Antioxidant enzymes and lipid peroxidation in the scalp of patients with alopecia. J Dermatol Sci 2002;29:85-90. [CrossRef]

14. Koca R, Armutcu F, Altinyazar CH, Gurel A. Evaluation of lipid peroxidation, oxidantantioxidant status, and serum nitric oxide levels in alopecia areata. Med Sci Monit 2005;11:296-9.
15. Kim SW, Kim BJ, Youn SW, Park KC, Huh CH. Evaluation of free oxygen radical and antioxidant capacity in alopecia areata. J Dermatol 2010;37:762-4. [CrossRef]

16. Lowry OH, Rosenbrough NJ, Farr AL, Randal RJ. Protein measurement with Folin phenol reagent. J Biol Chem 1951;193:26575.

17. Beutler E. Red Cell Metabolism: A Manual of Biochemical Methods, $3^{\text {rd }}$ ed. Grune and Stratton Inc: New York, 1984.

18. Fridovich I. Superoxide dismutase. Adv Enzymol Relat Areas Mol Biol 1974;41:35-97. [CrossRef]

19. Ohkawa H, Ohishi N, Tagi K. Assay for lipid peroxides in animal tissues by thiobarbituric acid reaction. Anal Biochem 1979;95:351-8. [CrossRef]

20. Latha B, Babu M. The involvement of free radicals in burn injury: a review. Burns 2001;27:309-17. [CrossRef]

21. Hovi T, Smyth JF, Allison AC, Williams SC. Role of adenosine deaminase in lymphocyte proliferation. Clin Exp Immunol 1976;23:395-403.

22. Terasaki PI, Mottironi VD, Barnett EV. Cytotoxins in disease: Autocytotoxins in lupus. N Eng J Med 1970;283:724-8. [CrossRef]

23. Hitoglou S, Hatzistilianou M, Gougoustamou D, Athanassiadou F, Kotsis A, Catriu D. Adenosine deaminase activity and its isoenzyme pattern in patients with juvenile rheumatoid arthritis and systemic lupus erythematosus. Clin Rheumatol 2001;20:411-6. [CrossRef]

24. Navarro R, Daudén E, Gallo E, Santiago Sánchez-Mateos D, García-Diez A. Alopecia Areata during Treatment of Psoriasis with Adalimumab and Leflunomide: A Case and Review of the Literature. Skin Pharmacol Physiol 2012;25:107-10. [CrossRef]

25. Javanbakht MH, Djalali M, Daneshpazhooh M, Zarei M, Eshraghian MR, Derakhshanian $\mathrm{H}$, et al. Evaluation of antioxidant enzyme activity and antioxidant capacity in patients with newly diagnosed pemphigus vulgaris. Clin Exp Dermatol 2015;40:313-7. [CrossRef]

26. Bekpinar S, Kiliç N, Unlüçerçi Y, Akdag-Köse A, Azizlerli G, Ozbek-Kir Z. Evaluation of nitrosative and oxidative stress in Behçet disease. J Eur Acad Dermatol Venereol 2005;19:167-71. [CrossRef] 